\title{
BIOLOGICAL AND LANDSCAPE VALUES OF THE FORMER RALSKO MILITARY TRAINING AREA
}

M. H o n c ů : Biological and landscape values of the former Ralsko military training area. - Geografie - Sborník CGS, 103, 3, pp. 300 - 319 (1998). - This paper gives a brief description of the recent state of the former military training area Ralsko and presents the evolution of nature conservation in this area. Moreover, it characterizes the damaging of natural conditions and gives an overview of scientific research carried out in this area. In future, the most valuable parts of the area will be protected within the National Nature Reserve Dokeské pískovce a mokřady (Doksy Sandstones and Wetlands) covering an area of 5,302 ha which will however include also some lands outside the former military training area.

KEY WORDS: former Ralsko military training area - nature protection - natural historical research.

\section{Nature conditions}

The region of the former Ralsko military training area is situated practically in the middle of the Ralská pahorkatina Hilly Land. Its relief is rather monotonous. An undulated sandstone hilly land is diversified by the hills of the Ralská pahorkatina Hilly Land dominating the landscape by their height (Ralsko $696 \mathrm{~m}$ a. s. l., Velký Bezděz $603 \mathrm{~m}$, Malý Bezděz $578 \mathrm{~m}$, Velký Jelení vrch Hill $514 \mathrm{~m}$ ). The hilly land is formed by volcanic rocks, partly by excised flues (most frequently basaltic, but also phonolitic and trachytic ones), partly by outcrops of Turonian sandstones. The height difference of the studied territory is $436 \mathrm{~m}$ (the lowest point being the Ploučnice River level near Veselí at an altitude of $260 \mathrm{~m}$, the highest one the Ralsko summit). The majority of the territory lays between 300 and $350 \mathrm{~m}$ a. s. $\mathrm{l}$.

A high percentage of forests (70\%) is typical of the region, at lower altitudes artificially planted pine and spruce monocultures prevail, at higher altitudes there are natural mixed or broad-leaved forests with beeches prevailing. Ponds are important landscape components of the region, mainly built in places of original lakes, moors or wetlands. The largest ones, the Břehyně (90 ha) and the Hamr Ponds (60 ha) are situated at the outer limit of the former military training area. The water network is composed of four pond systems: Doksy, Hradčany, Hvězdov - Nové Dvory and Stráž - Hamr. The territory is drained by the Ploučnice River and its affluents Hamerský, Ploužnický and Hradčanský potok Brooks. The eastern part belongs to the Jizera River basin with its affluents Bělá with Rokytka and Zábrdka with Mukařovský potok Brook. A greater part of the territory belongs to the Ploučnice River catchment area $(65 \%)$, the rest, about $35 \%$, to the Jizera River catchment area.

According to the biogeographical regionalization of the Czech Republic (Culek et al. 1996), the territory is situated in the Ralsko bioregion. It is an 
exceptionally important bioregion of azonal character with a number of relics. Among all the sandstone bioregions, this one has the most various biota where different qualities of sandstones and alternation of dry and wet localities on neovulcanites are represented.

\section{History of gamekeeping and nature protection}

The present nature preservation, in terms of its species diversity, is evidently due to the geomorphology of the region, but also to the conditions of former estates. The property conditions were stabilized there in the first half of the 18th century. The northern part of the territory belonged to the Mimon - Stráž pod Ralskem estate owned by counts of Hartig. The count family of Valdštejn, lords of Mnichovo Hradiště, Bělá pod Bezdězem and Doksy, owned the majority of lands in the central and southern part of the region, mainly large forest complexes. Until the beginning of the 17th century, the Hradčanské pohoří Mountains, rich in gorges, and Dubské Švýcarsko Rocks were inhabited by bears, and up to the middle of the 18th century by wolves and lynxes. Even now it is possible to find in the Hradčanské pohoří Mountains abandoned wolves lairs. A certain landscape protection was ensured by the creation of a game park in the Valdštejn estate in the Hradčany region in the second half of the 18th century which later covered 3,405 ha (see Wurm 1887), practically from Dvoudomí and Senná brána Gate up to Strážov. It was called Strážovská obora game park and deer, fallow deer and from 1926 also moufflon were kept there. Hunting lists from the year 1818 show the presence of deer, fallow deer, boar, roe, hare and pheasant, but also of other species living wildly such as for instance wood-grouse, heath cock, hazel hen, snipe, otter, wild cat, pouched marmot, falcon, eagle, Pandion, buzzard, wild goose, bittern, etc. (see Roller 1938). The game park existed there until 1945 when it was abolished as a result of war events. In the years 1977 - 1978, the game park called Velký Dub and covering 533 ha was renewed, the renewal being paid for by the Military forests and farms administration.

Landscape protection was consequently practised by the owner of the Valdštejn estate probably from 1910, when in the Hradčanské pohoří Mountains it was authorized, because of bird protection, to walk on marked paths only. In 1926, F. Firbas from the Institute of Botany, German University, Prague, proposed to enlarge the protection to Břehyně, Pecopala, Velká and Malá Buková, Slatinné vrchy Hills, Hradčanské stěny Walls, Hradčany Ponds and to a part of the Máchovo jezero Lake, which came into force in 1933 under the name of "Doksy region and Kummer Mountains". This reserve was of disjunctive character, and its total area was not known. In 1946, the Ministry of Education and Culture tried to enlarge the existing reserve to Zahrádky and Holany in the West and to Bělá and Kuřivody in the East. The project was not accepted because of the planned constitution of a military training area which came into force in October 1946 by a government decree. After a study of protected regions done in the years 1961-1962 it was stated that the protective statute of the protected region was being infringed by developing recreation activities (The Máchovo jezero Lake was a part of the reserve). Protection of the region was abolished and in 1967 substituted by proclamation of two individual reserves - Břehyně and Pecopala (903 ha) and Hradčany Ponds (144 ha). In 1972, the protection of Swamp, one of the 
western bays of the Máchovo jezero Lake situated outside the Ralsko military training area, was promulgated. Since 1967 the Ralsko Hill has been protected. Since 1993 protection has been applied to the Vranovské skály Rocks at the southern foot of the Ralsko and since the 1st of January 1996 to six territories in the neighbourhood of Hamr na Jezeře (Děvín, Ostrý and Schachstein, Velký and Malý Jelení vrch Hills, Černý rybník Pond peat-bog, Stohánek, Divadlo and Šroký kámen Stone).

\section{Landscape devastation}

The large territory spread over an area of 24,989 ha was largely unknown by the public as it was practically entirely inaccessible until 1990 . The prevailing opinion was that the nature in the military training area was completely destroyed, irreversibly damaged, devastated. The army (from 1946 the Czechoslovak, from 1968 the Soviet one) intensively used the airport, shooting ranges, training grounds, dormitories, roads. Nature was of course damaged, but it must be said that the Czechoslovak army was more respectful of the territory. The extent of local devastation caused by the Czechoslovak army mostly did not exceed the limit of ecological tolerability. The situation was quite different after the arrival of the Soviet army which introduced its way of living and its approach to nature. This was most dramatically manifested in the proximity of the Hradčany airport, where soil and water were contaminated by oil substances and aromatic hydrocarbons, dikes of the Hradčany ponds were destroyed or damaged. Frequent forest fires occurred about 200 ha of forests were burnt out around the Hradčany airport, building activities went on uncontrolled, many illegal dumps appeared. The whole region was heavily pyrotechnically stressed, forest ways destroyed by tanks. It turned out however that only some 10 to $15 \%$ of the total area were thus damaged, the other 85 to $90 \%$ remained practically untouched and extremely valuable from the natural historical viewpoint. In fact, practically no fertilizers, herbicides or pesticides were used there for nearly fifty years, practically no soil reclamation was done, neither recreation resorts nor larger settlements were built, industry did not develop. Anthropogenous impacts were almost natural - they manifested themselves in soil denudation due to the force of air masses, fire, etc.

Geological prospecting carried out in the years 1967 - 1972 discovered in a part of the territory an uranium deposit. Its extraction and the consecutive processing of uranium ore caused further devastation of the territory and its large deforestation. Beside the classical deep mining, chemical extraction was also used. This activity caused the serious contamination of strategic fresh water reserves by radionuclides or by solutions of strong acids in the watery Cretaceous groups of beds which are a part of the protected accumulation of underground waters of the North-Bohemian Cretaceous Basin. Different accidents caused contamination of littoral banks of the Ploučnice River and of a part of soils next to the uranium ore processing plant.

\section{Natural historical research}

Thanks to its natural riches, the marginal, western and northern parts of the former Ralsko military training area were the centre of attention of 
natural scientists of many branches. Of course it is not possible to mention here all their papers, but let us sum up at least the most important ones. The most numerous are botanical works. They were progressively published from the middle of the 19th century, when the forester Schauta (see Schauta 1861) elaborated the first list of the Mimoň region flora. Other ones followed (see for instance Reuss 1862). Many data from the region were collected by F. Celakovský (1868 - 1883, respectively 1875). Among them the information about the occurrence of Hammarbya paludosa near Staré Splavy, already known since Pöches findings in 1884 is very valuable. Evaluation of the flora of the then existing but also abolished ponds of the region was done by F. Wurm (1877). F. L. Sitenský $(1886,1891)$ presents a monograph of Bohemian wetlands and mentions the Pustý rybník Pond peat-bog near Strážov, the Rotten Meadows near Jestřebí or the peat-bogs in the neighbourhood of Mimon. Higher plants of the Mimoň region were studied by K. Fechtner (19888). F. Firbas (1927) made in the whole Doksy region pollen analyses in peat-bogs and swamps which helped him to consider the evolution of deposits. The Jestrebí swamps were studied by J. Anders $(1897,1916)$ who described in detail the local flora including mosses and lichens. K. Zimmermann (1917) presents a description of a swamp before its reclamation, J. Schuster (1931) informs us about changes which occurred there after reclamation in 1928. Nevertheless J. Klika (1933) did not succeed in the years 1930 and 1931 in finding here the Hammarbya paludosa that he found in Břehyně. V. Petríčcek (1987) proposes foundation of a state nature reserve Jestřebská blata moors, G. Janderová (1994) evaluated changes which would occur after the removal of the peat layer on a part of the swamp. T. Hájek (1996) summed up the findings on Jestrebí swamps. J. Dittrich (1933) mentions in his list of peat deposits their area and thickness, vegetation, degree of drainage and different used names. Great attention was paid to the queen of Jestřebí swamps Ligularia sibirica which is mentioned by a number of authors (for instance Schuster 1931, Jedlička 1932, Mattauch 1936, Prinz 1941 - 1942, Maršáková 1973). A new locality of Ligularia sibirica in the vicinity of the Ploužnice Village was registered by R. Dlouhý (1963). Pinquicula bohemica in the region of Jestřebí swamps was studied by K. Kubát (1981, 1985), R. Bělohlávková (1989) and mainly by M. Studnička (1989 and 1994). Dactylorhiza bohemica was described in this region by R. Businský (1989). The whole territory of Excursions-club was described by F. Hantschel $(1890,1892,1899,1916)$, the Doksy and Hradčany region by F. Pohl and F. Firbas (1922). Hradčanské stěny Walls were the object of the interest of J. Anders (1928), K. Prinz (1938), later of V. Ložek (1948) and mainly of T. Sýkora (1974 and 1975) who summed up findings done on this territory. P. Rychtařík (1990) verified there a second locality of Carex pediformis cf. macroura in Bohemia and F. Dubský (1938) mentions his finding of Daphne cneorum under the Vysoký vrch Hill. Hradčany beech forests were studied by T. Sýkora (1975). The Břehyně Pond and the neighbouring peat-bogs were described by R. Dlouhý (1963), R. Neuhäusel and R. Neuhäuselová (1965), M. Abtová (1987) and mainly by D. Stančík (1995 and 1996). R. Maximovič (1951) elaborated, within the forestry plan of the Hamr forests, a detailed natural historical evaluation of the whole region. The Pustý rybník Pond peat-bog near Strážov was investigated by Z. Dohnal (1960), who in another paper (1961) elaborated the Doksy peat and swamp deposits on the basis of the research results of the late 1950s. An extended botanical research within the mining area of the Hamr coal mine was done by 
A. Čvančara $(1974,1977)$, the most assiduous botanist of the region is T. Sýkora (1973, 1975, 1977, 1979 and 1988). The Hamr and the Hradčany ponds were studied by D. Turoňová (1978, 1985, 1987 and 1988). The region of Stráž pod Ralskem - Hamr was also described by P. Rychtařík (1988, 19992 and 1993). D. Turoňová (1994) recently elaborated the flora of the Máchovo jezero Lake, similarly as P. Rychtařík (1966).

Papers of zoological character deal with different branches. Research on plankton of the Máchovo jezero Lake was carried out by R. Lendenfeld (1901), small crustaceans - water-fleas (Cladocera) of the Máchovo jezero Lake were studied from 1899 by V.H. Landhaus (1911) who determined there 67 species. In 1909 a hydrobiological station was built there to serve mainly natural scientists of many branches. A worker at the station F.Schad-Roadwalk (1912) elaborated a contribution to a better knowledge of birds of the region. Also the geologist B. Müller (1914) worked there and explained the geological structure of the Máchovo jezero Lake and of its neighbourhood. Nesting places of Falco peregrinus near Hamr were examined by K. Loos (1915), whereas J. Mašek (1938) informed us about their nesting in the Hradčanské stěny Walls and J. Schuster (1933) near Jestřebí. The beetles (Coleoptera) of the Hradčany Mountains were explored by $\mathrm{H}$. Kral (1915, 1921), who determined about 2,800 Coleoptera species in this territory. Kral's research territory was nevertheless much larger than the Hradčany plateau - it was limited by the line Bezděz - Kuřivody - Ralsko - Mimoň, it lead through the Ploučnice Valley to Veselí and in the South it went to the large ponds of the Doksy system. The water beetles of the Máchovo jezero Lake region were studied by E. Sprenger (1922), the remarkable butterfly species of the region were described by J. Sterneck (1929), the ornithology of the Máchovo jezero Lake region and of the Hradčany Mountains was the object of studies of J. Schuster (1933, 1938), gamekeeping that of J. Roller (1938) and the fish populations of the Máchovo jezero Lake were studied by G. Japp (1938).

The research work went on also after World War II, although in very difficult conditions. It was even for a certain time virtually interrupted because of the constitution of the military training area. We have several papers from some marginal regions. For instance the zooplankton of the Máchovo jezero Lake and the Břehyně Pond was inventarized by V. Sládeček (1951) and A. Sládečková-Vinniková (1958), while I. Flasar (1964) inventarized the molluscs of the same territory. A series of inventarization enthomologic research studies were dedicated to the State Nature Reserve Břehyně-Pecopala (see Kopecký 1962, Hrdlička 1963, 1964, Novotní 1964). Flies, gad-flies (Tabanidae) and Asilidae of that region were inventarized by J. Moucha (1967). Several sources (see for instance Grund 1941-42, Heyrovský 1960, Malý 1965, Pešková 1985) inform us about Rosalia alpina occurrence on the Bezděz, while J. Hrdlička (1964) found it in Pecopala, Bezděz and Ralsko.

The situation was further complicated by the development of uranium mining. Researchers could nevertheless get access to the region with appropriate authorization. A more detailed natural research went on within preparatory activities for mining in the years 1971 - 1973 and it was organized by the Regional Centre of the State Monument and Nature Protection in Ústí nad Labem. The research was carried out by natural scientists of the North-Bohemian Museum in Liberec, the District Museum in Česká Lípa and the Regional Museum in Teplice. Their object of study was a region of about $60 \mathrm{~km} 2$ immediately affected by uranium extraction. The research was done in 9 branches of natural science and ascertained 
occurrence of 958 species of higher plants (Čvančara 1974), 149 species of mosses (Pilous 1974), 19 species of isopod crustaceans (Flasarová 1974), 91 species of molluscs (Flasar 1974), 1030 species of beetles (Honců 1974), 164 species of birds and 6 species of small mammals (Nevrlý 1974). Three new species of invertebrates (an isopod crustacean, a mollusc and a beetle) were newly found on the territory of the Czech Republic. This research was summed up by T. Sýkora $(1974,1977)$ who published a proposition to protect 18 localities, namely Ralsko (at that time already protected under the form of State Nature Reserve), Hamr Pond and Děvín Meadow, Vranov Rocks, Lipka (outside the military training area), meadows along the Ploučnice River next to Noviny pod Ralskem (outside the military training area), Mešné, Velký and Malý Jelení vrch Hills, Černý rybník Pond, Děvín and Ostrý Hills, Šroký kámen, Stohánek, Divadlo, Chrastný vrch Hill, Kundratice peat-bog, Kavčí kameny Stones, Květnaté bory pine-woods at Cerná Novina, covered podzol soils at Cerná Novina and a sand dune above the Černý rybník Pond.

In 1984, the Hamr Pond was discharged for security reasons due to uranium mining activities. From the first moment it was clear that it would affect the well-preserved locality of peat and bank segments Děvín Meadow (a 95 ha large peat-bog). Already in 1986 the locality was seriously menaced by drying up. The district authorities in Česká Lípa charged the Hamr Uranium Mines to build a protective dam in the upper part of the pond which was done in 1987. At the same time, inventarization research was started there (1985 - 1987) in 10 basic branches which brought a series of new findings, including determination of the protection value of the territory. Botanical research verified 312 plants out of 380 determined there in the years $1971-1973$ (Rychtařík 1988). D. Turoňová (1985) described there a new association of plant communities of small brooks: Cardamino-Beruletum erecti. During the zoological research, 223 beetle species (Honců 1988) and 240 butterfly species were found, one of them for the first time in Bohemia (Horák 1988), then 133 mite species, out of them 2 quite new and 4 new in the Czech Republic (see Miko 1988). As for vertebrates, only birds were studied -80 species of them were determined in the region (Pelc 1988). A complex evaluation of this research was done by T. Sýkora (1988).

In 1984, a complex botanical evaluation of the whole territory of the Ralsko military training area was done for the Czechoslovak Army by the staff of the Institute of Botany, Czechoslovak Academy of Science, headed by J. Kopecký (see Kopecký, ed. et al. 1986). This research was repeated in 1991 and, with the help of the Czech Institute of Nature Protection, Prague, damage to vegetation caused by the Soviet Army was determined. With regard to individual studies of specialists working in that territory, 11 localities were proposed for territorial protection, some of them were already proposed after the research of 1971-73 (Velký and Malý Jelení vrch Hills, Stohánek, Široký kámen Stone, Chrastný vrch Hill). Newly proposed were Spičák (outside the military training area), the Ploučnice River alluvial plain, the Ploužnice Brook alluvial plain between Hvězdov and Dolní Okna, Hradčany Pond, Hradčany Walls, the Bělá River Valley with its affluents above the former Vrchbělá Village and a part of the Vrchbělá shooting range. This proposal was published by J. Husáková and V. Větvička (1992). The staff of this institute evaluated the territory of the former Ralsko military training area as the most valuable out of all the former military areas and that in spite of the fact that its core is formed by floristicly and vegetationally highly uniform pine forests on acid soils. About 700 taxons of higher plants were determined 
there, out of them 27 protected species. A phytocenologic map was elaborated for a part of the territory and nearly 90 plant associations were determined (see Balátová et al. 1997).

Further intensive research went on there in the years 1992-95 under the auspices of the Agency for Nature Protection, Prague, and the District Museum, Česká Lípa, in which specialists of other institutions also took part. The results of this research were published in a monothematical issue of the local national historical journal of the Česká Lípa region - Bezděz (No 5) dedicated to the Ralsko military training area (22 natural scientific and 3 historical contributions). The research resulted in the determination of 31 species of small phyllopod crustaceans (Stifter 1997; Zavadil, Honců 1997), 224 spider species, 2 of them for the first time in Bohemia (Kurka 1997), 24 dragon-fly species (Honců 1997), 38 species of orthopterous (Honců 1997), 303 species of ground beetles, 4 out them newly in Bohemia (Honcư, Vonička 1997), 18 species of scarabs (Vonička 1997) and nearly 1100 butterfly species, 4 of them new in the Bohemian fauna (Bouma 1997; Vávra et al. 1977). As far as vertebrates are concerned, one species of cyclostomous, 26 species of fish, 6 species of reptiles, 44 species of mammals (all Vitáček 1997) and 59 species of birds (Vitáček 1997, Kurka 1997; Šrubař 1997) were determined. Recently, special attention has been paid to the observation of eagles (Haliaetus albicilla) and cranes (Grus grus) - Vondráček, Honců 1990; Kurka 1991).

\section{Conclusion}

After evaluating all natural scientific research works, it is possible to state that the region of the former Ralsko military training area belongs, at least partly, to the most valuable natural scientific regions of Bohemia. In fact, about 1,200 species of higher plants and 90 plant associations were determined there and an incredibly high number of especially protected plant species (145) occur there. Species that were for nearly 20 years considered extinct grow in the barely accessible swamps. They are rare orchidaceous Hammarbya paludosa and Dactylorhiza incarnata subs. serotina (see Honců, Joža 1995; Honců 1995). In the sandstone rocks of the Hradčany Walls and Vranov Rocks at the Ralsko foothill, as well as in the rocks near Hamr, other botanical treasures grow, for instance Minuartia caespitosa (which has here its only locality in Bohemia), Carex pediformis subsp. macroura - which has two localities in Bohemia, Astragalus arenarius and Chimaphila umbellata that occur in Bohemia in only three localities. We can find there thermopile species as Stipa joannis, Pulsatilla patens or Pulsatilla pratensis subsp. bohemica which contrast with mountain - dealpine - ones, as Thesium alpinum, Sesleria albicans or Biscutella laevigata subsp. varia and others. In the Jestrebí swamps, next to the military training area but on the lands of Military Forests and Farms, Mimoň, it is possible to find Ligularia sibirica, Dactylorhiza maculata subsp. maculata, Liparis loezelli and two endemites: Pinquicula bohemica and Dactylorhiza bohemica.

Similar results were obtained in zoological research, intensified since 1991. The number of determined insect species has already reached several thousand. Two mite species were found, probably quite new to science and a series of species new to Bohemian fauna: 1 species of isopod crustacean, 4 mite species, 2 spider species, 1 mollusc, 6 beetle species and 5 butterfly species. The occurrence of the critically endangered Rosalia alpina is very 


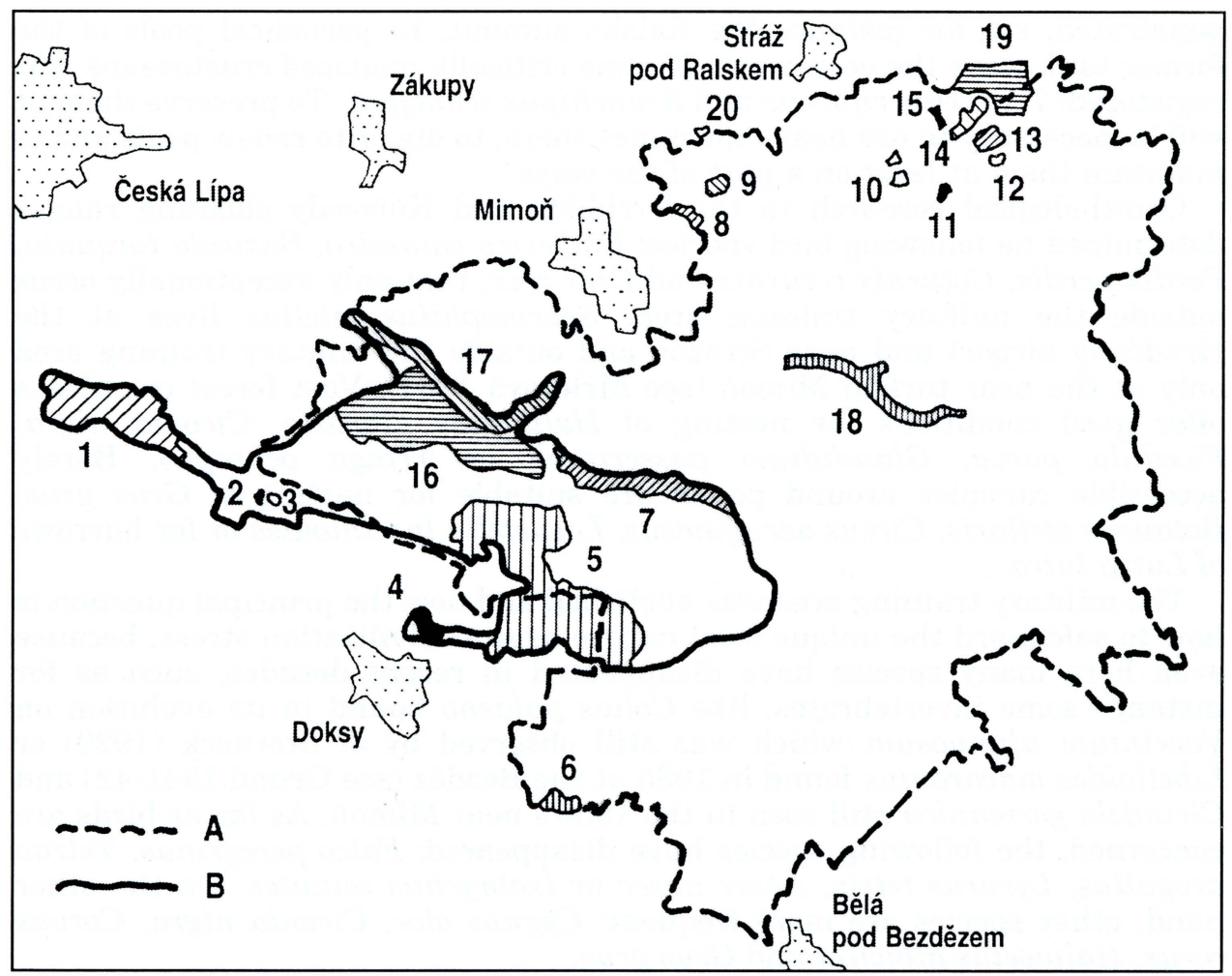

Fig. 1 - Protected regions of the former Ralsko military training area and of the proposed National Nature Reserve Doksy Sandstones and Wetlands. A - limits of the former Ralsko military training area, B - limits of the proposed National Nature Reserve Doksy Sandstones and Wetlands. 1 - National Nature Reserve Novozámecký rybník, 2 - Nature Reserve Slunečný dvůr, 3 - Nature Monument Konvalinkový vrch, 4 - National Nature Monument Swamp, 5 - National Nature Reserve Břehyně-Pecopala, 6 - Nature Reserve Velký a Malý Bezděz, 7 - Nature Reserve Hradčanské rybníky, 8 - Nature Monument Vranovské skály, 9 - Nature Reserve Ralsko, 10 - Nature Monument Velký a Malý jelení vrch, 11 - Nature Monument Stohánek, 12 - Nature Monument Divadlo, 13 - Nature Monument Siroký kámen, 14 - Nature Monument Děvín, Ostrý a Schachtstein, 15 - Nature Monument Rašeliniště Černého rybníka. Temporarily protected territories: 16 - Hradčanské stěny, 17 - Údolní niva Ploučnice, 18 - Ploužnické mokřady. Some proposed protected territories: 19 - Hamerský rybník and Děvínská louka, 20 - Průrva Ploučnice (Noviny pod Ralskem).

rare in Bohemia.The mountain character of the region is confirmed by several insect species occurring in higher parts of hills in the northern part of the territory (for instance Chrastný, Děvín, Velký and Malý Jelení vrch Hills, Ralsko), which eventually descend into inversion valleys, pond basins or peatbogs to an altitude of about $300 \mathrm{~m}$. The presence of these mountain species can be explained by a zonal shift of local climate (Vávra et al. 1997). Although the northern part of the territory is at present isolated from mountain regions, a continuity with the mountain fauna of the Lužické, eventually the Jizerské hory Mountains, was highly probable in the past. It means that the mountain species in the territory are relics. Thermophile species do not much impose themselves in the region, although they live on southern slopes of the hills. In some places, thermophile and mountain species are mutually 
penetrated, see for instance the Ralsko summit. In periodical pools of the former tank ways the occurrence of some critically menaced crustaceans was registered: Trips cancriformis and Branchipus schaefferi. To preserve them, it will be necessary to use heavy machines there, to dig or to renew pools and to maintain them at least on a part of the ways.

Ornithological research in the Vrchbělá and Kuřivody shooting ranges determined he following bird species: Emberiza calandra, Saxicola torquata, Perdix perdix, Coturnix coturnix and Crex crex, that only exceptionally occur outside the military training area. Spermophilus citellus lives at the Hradčany airport and near Strážov and outside the military training area only at the near turf in Mimoň (see Mrlíková 1997). Vast forest complexes offer good conditions for nesting of Haliaeetus albicilla, Ciconia nigra, Ficedula parva, Glaudidium passerinum or Tringa ochropus. Barely accessible canopies around ponds are suitable for nesting of Grus grus, Botaurus stellaris, Circus aeruginosus, Locustella luscinioides or for burrows of Lutra lutra.

The military training area was abolished and now the principal question is how to safeguard the unique local nature against civilization stress, because even here many species have disappeared in recent decades, such as for instance some invertebrates, like Colias palaeno bound in its evolution on Vaccinium uliginosum which was still observed by J. Sterneck (1929) or Libelloides macaronius found in 1935 at the Bezděz (see Grund 1941-42) and Cicindela germanica still seen in the 1950's near Mimoň. As far as birds are concerned, the following species have disappeared: Falco peregrinus, Tetrao urogallus, Lyrurus tetrix, Anser anser or Ixobrychus minutes. On the other hand, other species are more frequent: Cygnus olor, Ciconia nigra, Corvus corax, Haliaeetus albicilla and Grus grus.

The nature protection authorities are struggling for territorial protection of the most precious nature parts. For that reason, new protected territories have been promulgated: the Vranovské skály Rocks in 1993 and in the same year the protection of Malý Bezděz was enlarged to Velký Bezděz. Since the 1st of January 1996 six other localities in the Hamr region have been newly protected: Stohánek, Šroký kámen Stone, Divadlo, Velký and Malý Jelení vrch Hills, Černý rybník Pond peat-bog, Děvín, Ostrý and Schachstein. Other localities have been protected for a limited period, like for instance, since 1993, the Ploužnice wetlands between Hvězdov and Dolní Okna, Hradčanské stěny Walls and the Ploučnice alluvial plain between Hradčany and Veselí. The protection of several other localities is being prepared. For the moment they remain in the category of important landscape elements: they are the Hamr Pond and the Děvín Meadow, the Ploučnice River Ravine in Noviny pod Ralskem, Lipka, Kavčí kameny Stones, Květnaté bory pine-woods near Holičky, Slatinné vrchy Hills. On the territory there are several other localities that will probably remain only important landscape elements, such as for instance the Dlouhý kámen Stone near Hamr, Jelení and Liščí vrch Hill near Boreček, Čertův žleb Glen at Těšnov, etc. The territory is interwoven by a network of national and regional biocentres and biocorridors that cannot be described in this paper because of its limited extent. Some territories which were in previous years proposed for protection have been destroyed or heavily damaged. Already at the beginning of this century the so-called Certova zed Wall at the eastern margin of the Kurivody shooting range was mined away, as well as the lateral Certova zed' Wall near Ploužnice. Only a trench that is progressively getting filled by soil or overgrown by trees has remained. 
Anyway, the efforts to save the Čertova zed' Wall are described by numerous authors (see for instance Wurm 1879, 1884; Fendrych 1916; Ksandr 1959, $1960,1962)$. Other localities were destroyed recently by uranium mining - see for instance the clearing away of pine-spruce forests and peat pine woods of European taiga with occurrence of Ledum palustre on an area of almost 2 ha in the Mšený Forest near Stráž pod Ralskem, mining away of the sand dune above the Cerný rybník Pond, quarrying away of the top of the Lipka Hill, mining away of balneologic peat at Noviny pod Ralskem for the needs of the Kundratice spa, or afforestation of covered podzols at Černá Novina.

In 1993, the Czech Institute for Nature Protection, Prague, proposed the establishment of the National Nature Reserve Doksy Sandstones and Wetlands. This proposal is based on previous research and backed by the conception of the original protected territory from the year 1933 "Doksy Region and Kummer Mountains". It includes the most valuable parts of the former Ralsko military training area, like the National Nature Reserve Břehyně Pond with a vast heath on a flat water shed known as Pustý rybník Pond peat-bog, the Pecopala sandstone plateau penetrated by the Pecný basaltic dome and grown on by beech forest, Hradčanské stěny Walls with a rock town rich in geomorphological forms as rock cavities, rock windows, a rock gate and rock hats with relic vegetation on sandstone rocks, the alluvial plain of the non-regulated Ploučnice River forming between Hradčany and Veselí a balanced alluvial ecosystem, the Nature Reserve Hradčany Ponds up to the Velká and Malá Buková Hills with remnants of the original beech forests on both erupted hills. Outside the Ralsko military training area it will include the most valuable territory of the Dokeská pahorkatina Hilly Land with the National Nature Reserve Novozámecký rybník Ponds, the major part of the Jestřebí swamps, that is the existing reserve Sluneční dvůr, Konvalinkový vrch Hill, the so-called Baronský rybník Pond and the Rotten Meadows, bays and islands of the Máchovo jezero Lake including the existing National Nature Monument Swamp. With its area of 5,302 ha (including the protective belt), it will be one of the largest small-area protected regions in Bohemia.

\author{
References:
}

\title{
Landscape shaping, nature protection:
}

ABTOVÁ, M. (1988): Hamerský rybník, zrrízení chráněného území. In Základní přírodovědná dokumentace Hamr II. Základní organizace ČSOP 01/33, Praha, pp.353-357.

BLAŽKOVÁ, J. (1997): Vznik vojenského újezdu Ralsko. Bezděz, 5, Ceská Lípa, pp. 9-46.

CULEK, J. et al. (1996): Biogeografické členění České republiky. Enigma, Praha, 347 p.

ČEKALOVÁ J., (1992): Co zničili Sověti. Bohatství vojenských výcvikových prostorů. Nika, Praha, 2, pp. 60-61.

DITTRICH, J. (1933): Die Moore Nordostböhmen. Sebastianberg.

Dílčí zpráva o Základním přírodovědeckém průzkumu Hamerského rybníku a rašeliniště Děvínská louka. Základní organizace ČSOP 01/33, Praha 1986. Ms., 26 p.

DOHNAL, Z. (1960): Rašeliniště "Pustý rybník" u Mimoně. Ochrana př́rody, Praha, 15, pp. 172-174.

DOHNAL, Z. (1961): Rašeliniště a slatiniště Polomených hor. Antropozoikum, Praha, 9, pp. 241-276.

Ekologie - Zelená kniha o Ralsku. Praha, Ralsko 1992. Ms., 122 p.

FAINA, R., PŘIKRYL, I., (1995): Studie rybářského hospodaření. Rybník Břehyně. Výzkumný ústav rybáŕský a hydrobiologický. Vodňany. Ms., 14 p.

FIRBAS, F. (1924): Studien über der Standortscharakter auf Sandstein und Basalt. Ansiedlung und Lebensverhältnisse der Gefässpflanzen in der Felsflur des Rollberges in Nordböhmen. Beih. bot. Centralbl., Dresden, 40, pp. 253-409. 
FIRBAS, F. (1927): Die Geschichte der Nordböhmischer Wälder und Moore seit dem letzten Eiszeit. Untersuchungen in Polzengebiet. Beih. Bot. Centralbl., Dresden, 43, No. 2, pp. 145-219.

HONCÜ, M. (1992): Vypracování koncepce pro ekologickou stabilitu krajiny bývalého VVP Ralsko. Návrh na utváření chráněných krajinných útvarů, území a zón. Ms., 30 p. Uloženo v OVM Česká Lípa.

HONCŮ, M. (1996): Př́ehled chráněných území podle zákona č. 114/92 v širší zájmové oblasti jihozápadního předpolí ložiska Stráž pod Ralskem. Ms., 23 p., 1 map. Saved in OVM Česká Lípa.

HUDEC, K., HUSÁK, Š., JANDA, J., PELLANTOVÁ, J. (1995): Mokřady České republiky. Upravený dotisk 2 verze. Český Ramsarský výbor, Třeboň, 191 p.

HUSÁKOVÁ, J., SÁDLO, J., VĚTVIČKA, V. (1992): Vojenské výcvikové prostory a příroda. Ochrana prírody, 47, No. 3, Praha, pp. 67-71.

HUSÁKOVA, J., VÉTVIČKA, V. (1992): Bude bohatství přírody zachováno? Vojenskoekonomicko-ekologický časopis. HT ČSA, 1/4, Praha, pp. 30-32.

JANDEROVÁ, G. (1994): Posouzení vlivu plánovaného odtěžení ložišsa rašeliny na mokřadu Jestřebské rašeliniště. Diplomová práce, Fakulty stavební, ČVUT, Praha, 54 p., photos.

JEDLIČKA, V., (1930): Státní výzkumná stanice rybár̆ská a hydrobiologická v Doksích (k dvacetiletému výročí jejímu založení). Bezděz, Ceská Lípa, pp. 20-24.

KUNCOVÁ, J. (1997): Zájmy ochrany prrírody ve vojenském prostoru Ralsko a přilehlých území. Bezděz, 5, Česká Lípa, pp. 525-533.

KUNCOVÁ, J., KOUTECKÝ, B. a kol. (1998): Plán péče pro navrženou národní př́rodní rezervaci Dokeské pískovce a mokřady. Ms., 480 p., maps. Saved in AOPK, středisko Ústí nad Labem.

KÜHN, P. (1997): Radioaktivní znečištění údolní nivy Ploučnice v bývalém VVP Ralsko. Bezděz, 5, Česká Lípa, pp. 165-187.

LANGHANS, V. (1923): Die Forschungstation für Fischzucht und Hydrobiologie im Hirschberg (Böhmen). Mitt. Exc. Cl., Ceská Lípa, pp. 54-60.

MAXIMOVIC, R. (1951): Př́rodní poměry LC Stráž pod Ralskem - Hamr pro decenium 1951 - 1960. Ms., 114 p. Uloženo v Severočeském muzeu Liberec.

MEJSTŘÍK, V. (1975): Rašeliniště Děvínská louka v Hamru u České Lípy. Sborník Severočeského muzea, Ser. Natur, Liberec, 7, pp. 61-70.

Ochranářsko-přírodovědný prủzkum oblasti Hamru u České Lípy. TIS, Praha 1974. Part 1 - 178 p., Part 2 - 140 p., Appendix 95 p. Saved in AOPK Praha, AOPK středisku Ústí nad Labem, Severočeském muzeu Liberec, OVM Česká Lípa.

PEJŘIMOVSKÝ, J. (1983): Stav a vývoj vodohospodářských poměrů a lesních porostů v, okolí Břehyňského rybníka, Hradčanských rybníkủ a na rašeliništi Pustý rybník. Ústav pro hospodáŕrskou úpravu vojenských lesů a statků, Praha. Ms., 29 p. Saved in AOPK, středisko Ústí nad Labem.

PETŘÍČEK, V. (1987): Sít maloplošných chráněných území vybraných částí severočeského kraje se zretelem na druhovou ochranu. Severočeskou př́rodou, 20, Litoměřice, pp. 6369.

PETŔÍČEK, V. (1992): Zpráva o stavu ochrany př́rody v bývalých vojenských výcvikových prostorech po sovětské armádě. Ochrana přírody, Praha, 47, 282 p.

PETŘÍČEK, V., PLESNÍK, J. (1994): Ochrana přírody v bývalém VVP Mladá a Ralsko již "v civilu". Ochrana přírody, 49, No. 9, Praha, p. 284.

RYCHTAŘIK (1993): Generel lokálního ÚSES oblasti Stráž pod Ralskem - Hamr u České Lípy. Ms, 90 p., Appendix 24 p. Saved in Okresní úřad Česká Lípa, referát životního prostředí.

SITENSKÝ, F., L., (1886): O rašelinách českých se stanoviska př́rodovědeckého i hospodářského se zřením ku rašelinám zemí sousedních. Archiv pro př́rodovědecké zkoumání Čech. VI., č.1, Praha, 63 p.

SKLENIČKA, J. (1992): Lokální územní systém ekologické stability katastrů a části katastrů: Hvězdov, Strážov, Boreček, Ploužnice, Svébořice. Ms., 21 p., 52 tab. Saved in Okresní úřad Česká Lípa, referát životního prostředí.

SKLENIČKA, J. (1993): Lokální systém ekolologické stability, jih bývalého VVP. Praha, ms, 27 p., 127 tab. Saved in Okresní úřad Česká Lípa, referát životního prostředí.

ŠEVČÍK, L., HRDLIČKA, J. (1964): Chráněná území Severočeského kraje. Part I. Ochrana príírody, 19, No. 10, Praha, p. 165.

ŠIMÁČEK, F. (1933): Velký rybník dokeský (Máchovo jezero) a rybník Břehyňský. Bezděz, 4, Ceská Lípa, pp. 75-77. 
ŠTĚPÁN, V., J. (1932): Rybníky v Polomených horách severních Čech po stránce stavebnětechnické a geologické. Vodňany.

Základní přírodovědecký prủzkum údolí Ploučnice, úsek Mimoň - Boreček. Základní organizace ČSOP 01/33, Praha 1985. Ms., 482 p., 46 photos.

Základní inventarizační průzkum Hamerský rybník - Děvínská louka. Základní organizace ČSOP 01/33, Praha 1988. Ms., 357 p.

ZIMMERMANN, K. (1917): Die Erhaltung der Moore als Naturdenkmäler. Das Habsteiner Wiesenmoor "Der Wüste Teich". Mitteilungen des Nordb. Ver., f. Heimatforschung und Wanderpflege, Reichenberg, 1, pp. 23-31.

\section{Geology and geomorphology:}

ADAMEC, J. (1997): Vývoj poznání geologické stavby západní části VVP Ralsko. Bezděz, 5, Česká Lípa, pp. 85-146.

FENDRYCH, O. (1916): Č́ertova zed’ u Světlé, ohrožená přírodní památka. Krása našeho domova. 9, No. 7, Praha, pp. 1916-1917.

HAVRÁNEK, P. (1982): Inventarizační geologický průzkum CHPV Čertova zed’. Ms., 6 p. Saved in AOPK, středisko Ústí nad Labem.

HNÍDEK, R. (1930): Čertova zed’. Bezděz, 1, Česká Lípa, pp. 100-104.

KETTNER, R. (1932): Zpráva o dnešním stavu "Čertovy zdi” u Č̉eského Dubu. Krása našeho domova, 24, No. 7, Praha.

KINSKÝ, B. (1934): Pusté kostely (Hundskirchen). Bezděz, 5, Česká Lípa, pp. 88-91.

KSANDR, J. (1959): Historie a dnešní stav státní pŕírodní rezervace "Certova zed". Ochrana přírody, Praha, pp. 36-47.

KSANDR, J. (1961): Čertova zed’ a další možnosti jejího průzkumu. Ochrana přírody, Praha, p. 122.

KSANDR, J. (1962): Čertova zed’, geologický unikát Severočeského kraje. Sborník Severočeského Muzea. Ser. Natur., Liberec, pp. 3-12.

KÜHN, P. (1997): Pozůstatky staré těžby na jižním úbočí Hamerského Špičáku. Bezděz, 5, Česká Lípa, pp. 147-164.

MIKULÁŠ, R. (1997): “Železné klády” výjimečné skalní útvary v křídových pískovcích Ralské pahorkatiny. Ochrana př́rody, 52, No. 4, Praha, pp. 117-118.

MÜLLER, R. (1878): Auf die Teufelsmauer. Mitt. des Ver. für Heimatkunde des Jeschken und Isergebirges. Reichenberg.

MÜLLER, B. (1914): Der geologische Aufbau des Hirschberger Teichgebietes. Monogr. und Abh. z. Itern. Revue d. Ges. Hydrobiologie und Hydrografie. Leipzig, Bd. 5.

RUBÍN, J. (1997): Hradčanské stěny opět přístupné. Geografické rozhledy, 6, No. 4, Praha, pp. 110-112.

WURM, F. (1879): Eine Excursion auf die Teufelsmauer. Mitt. des Nordb. Exc. Clubs, Česká Lípa, II., 4 p.

WURM, F. (1884): Die Teufelsmauer zwischen Oschitz und. Bohm. Aicha. Verlag des Nordb. Exc. Clubs, Česká Lípa, 35 p.

\section{Botany:}

ABTOVÁ, M. (1987): Ostřice tlapkatá velkonohá - Carex pediformis C. A. Meyer subsp.macroura (Meinsch) Podpěra. Památky a příroda, 1, Praha, p. 65.

ABTOVÁ, M. (1988): Botanický inventarizační průzkum SPR Břehyně-Pecopala. Dílčí zpráva. Ms., saved in AOPK, středisko Ústí nad Labem.

ANDERS, J. (1897): Das Habsteiner Torfmoor. Botanische Skizze. Mitt. d. Nordb. ExcClubs, Česká Lípa, 20, pp. 79-86.

ANDERS, J. (1916): Neue Pflanzenfunde. Pilzstudien. Vom Habsteiner Torfmoor. Ein Pulsatilla-Ausflug. Mitt. d. Nordb. Vereines f. Heimatforschung und Wanderpflege, Reichenberg, 39, pp. 162-165.

ANDERS, J. (1928): Die Flechtenflora des Kummergebirges im Nordbhmen. Lotos, Praha, 76, pp. 315-326.

BALÁTOVÁ, E., HUSÁK, Š., HUSÁKOVÁ, J., HUSOVÁ, M., KOPECKÝ, K., VĚTVIČKA, V. (1997): Předběžný přehled rostlinných společenstev bývalého VVP Ralsko s poznámkami k vegetaci. Bezděz, 5, Česká Lípa, pp. 189-202.

BĚLOHLÁVKOVÁ, R. (1989): Tučnice česká - Pinquicula bohemica Krajina. In: Slavík, B. a kol.: Vybrané ohrožené druhy flóry ČSR. Studie ČSAV, 10, Academia, Praha, pp. 8193.

BUSINSKÝ, R. (1989): Dactylorhiza bohemica - nový druh objevený v severních Čechách. Preslia, Praha, 61, pp. 289-314. 
ČELAKOVSKÝ, F. (1868 - 1883): Prodromus květeny české. Praha, 908 p.

ČELAKOVSKÝ, F. (1875): Prodromus der Flora von Böhmen. Praha, 694 p.

ČVANČARA, A. (1974): Zpráva o základním floristickém průzkumu (vyšší rostliny) Ralské pahorkatiny v letech 1971-73. In Ochranářsko-přírodovědecký průzkum oblasti Hamr u Ceské Lípy. TIS Praha, pp. 155-341.

ČVANČARA, A. (1976): Floristické poměry severovýchodní části Ralské pahorkatiny. Sborník Severočeského muzea. Ser. Natur, 8, Liberec, pp. 3-50.

ČVANČARA, A. (1977): Floristické poměry severovýchodní části Ralské pahorkatiny II. Sborník Severočeského muzea. Ser. Natur, 9, Liberec, pp. 3-30.

ČVANČARA, A. (1987): Ohrožené a vzácné druhy Dokeska a Českolipska. In: Kubát, K. (red.): Ohrožené a vzácné druhy severočeského kraje. Materiály ze semináře. Severočeskou přírodou, 20, Litoměřice, pp. 81-85.

DBK., DUBSKÝ, F. (1938): Nová lokalita lýkovce vonného v Čechách. Bezděz, 9, Česká Lípa, pp. 30-31.

DLOUHY, R. (1963): Nález další lokality popelivky sibiřské. Ochrana př́rody, 18, Praha, p. 126.

DLOUHÝ, R. (1963): Základní botanický výzkum ve východní části SPR Břehyně. Okolí prameništ povodí. Ms., 18 p. Uloženo v AOPK, středisko Ústí nad Labem.

DLOUHÝ, R. (1967): Př́íspěvek k metodě základního výzkumu SPR. Čs. ochrana prírody, 3, Bratislava, pp. 39-49.

DOLEJŠ, K. (1988): Setoria orchidearum Westend na Liparis loezelii (L.), H. C. Rich v severních Čechách. Severočeskou přírodou, 21, Litoměřice, pp. 89-92.

FECHTNER, K. (1888): Zur Kenntniss der Flora des Gebietes von Leipa, insbesondere des Gegend von Niemes. Mitt. nordb. Exc.- Cl., Lípa, 11, pp. 315-317.

FIRBAS, F., POHL, F. (1926): Aus der Pflanzenwelt Nordböhmens I. ber einige Grundzge in der Gliederung der Pflanzendecke zwischen Mittelgebirge und Jeschken. Mitt. Nordb. Ver. Heimatforschung und Wanderpflege. Reichenberg, 49, pp. 1-9.

FIRBAS, F. (1937): Ein Nordböhmischer Beitrag zur pollenanalytischen Behandlung der Heidefrage. Natur und Heimat, Aussig, pp. 10-16.

HẤJEK, T. (1996): Jestřebská blata na Ceskolipsku a jejich ohrožená květena. Maturitní práce, 53 p. Saved in AOPK Praha.

HANUŠ, J. (1930): Hamerské jezero s Děvínem. Bezděz, 1, Česká Lípa, pp. 96-100.

HANTCHEL, F.(1890): Botanischer Wegweiser im Gebiete des Nordböhmischen Excursions-Clubs. Česká Lípa, 260 p.

HANTSCHEL, F. (1892): Beiträge zur Flora des Clubgebietes. Mitt. nordb. Exc.- Cl., 15, Česká Lípa, pp. 15-28.

HANTSCHEL, F. (1899): Beiträge zur Flora des Clubgebietes. Mitt. nordb. Exc.- Cl., 22, Česká Lípa, pp. 71-73.

HANTSCHEL, F. (1916): Beiträge zur Flora des Vereinsgebietes. Mitt. nordb. Exc., 39, Česká Lípa, pp. 14-21.

HLAVÁČEK, R., PYŠEK, R. (1988): Bylinná společenstva nivy Ploučnice mezi Mimoní a Borečkem (okres Česká Lípa). Severočeskou př́rodou, 21, Litoměřice, pp. 31-66.

HONCŮ, M., JÓŽA, M. (1995): Ohrožené druhy vstavačovitých na Dokesku. Živa, Praha, 43 , pp. 62-63.

HONCU, M. (1995): Vstavačovité (Orchıdacae) Českolipska. Bezděz, 3, Česká Lípa, pp. 91-167.

HUSÁKOVÁ, J., VĚTVIČKA, V. (red.), BALÁTOVÁ, E., HUSOVÁ, M., (1991): Posouzení problematiky ekologických škod způsobených sovětskou armádou ve VVP Ralsko, zvláště pak na chráněných částech přírody z hlediska botaniky. Závěrečná zpráva. Průhonice. Ms., 39 p.

JAPP, G. (1938): Die Pflanzenwelt des Hirschberger Grossteiches. In Laurin: Hirschberg und sein Teichgebiet, Druck G.Ribert, Haida, pp. 15-18.

JEDLIČKA, V. (1932): Popelivka sibiřská, vzácná rostlina Máchova jezera ohrožena. Bezděz, 3, Česká Lípa, pp. 28-29.

KLIKA, J. (1932): Nové stanoviště řečanky mořské a řečanky menší. Časopis Národního muzea, Sect. Natur, 106, Praha, pp. 67-88.

KLIKA, J. (1933): Nové stanoviště měkkyně bahenní Malaxis paludosa Sw. Časopis Národního Muzea, oddíl př́r., 107, Praha, pp. 47-49.

KOLBEK, J., PETŘIĆCEK, V. (1979): Vegetace Malého a Velkého Bezdězu a její vztah k Českému Středohoří. Sborník Severočeského Muzea, Přír. vědy, 11, Liberec, pp. 5-96.

KOPECKÝ, K., (red.), BALÁTOVÁ, E., HROUDA, L., HUSÁKOVÁ, J., HUSOVÁ, M., MLADÝ, F, VÉTVIČKA, V. (1985): Fytocenologické podklady k biologické asanaci VVP 
Vyškov, VVP Boletice VVP Jince, VVP Ralsko a VVP Mladá. Závěrečná výzkumná zpráva. Ms., 517 p. Saved in MNO Praha.

KŘIVSKÝ, A. (1977): Inventarizační průzkum lesnický státní přírodní rezervace Malý Bezděz. Ms., saved in AOPK, středisko Ústí nad Labem.

KŘIVSKÝ, A. (1981): Inventarizační průzkum lesnický SPR Břehyně-Pecopala. Ms., 40 p. aved in AOPK, středisko Ústí nad Labem.

KŘIVSKÝ, A. (1981): Inventarizační průzkum lesnický SPR Hradčanské rybníky. Ms., 30 p. Saved in AOPK, středisko Ústí nad Labem.

KŘIVSKÝ, A. (1981): Inventarizační průzkum lesnický SPR Ralsko, okr. Česká Lípa. Ms., 29 p. Saved in AOPK, středisko Ústí nad Labem.

KUBAT, K., LORBER, J. (1973): Diphasium complanatum (L.) Rothm. a Lycopodium clavatum v Severočeském kraji. Severočeskou př́rodou, 4, Litoměřice, pp. 53-72.

KUBÁT, K. (1974): Diphasium issleri (Romy) Holub a D.tristachyum (Pursh.) Rothm. v Čechách a na Moravě, 46, Preslia, Praha, pp. 310-318.

KUBÁT, K. (1981): Tučnice obecná česká - Pinquicula vulgaris ssp.bohemica, 29, Živa, Praha, p. 12.

KUBÁT, K. (1982): Rozšíření Lycopodiella inundata, Diphasium complanatum a D. zeilleri v Čechách a na Moravě. Severočeskou přírodou, 13, Litoměřice, pp. 13-30.

KUBÁT, K. (1985): Tučnice obecná česká - Pinquicula vulgaris L. ssp. bohemica (Krajina) Domin. Památky a príroda, No. 2, Praha.

KUBÁT, K. (1986): Červená kniha vyšších rostlin Severočeského kraje, 1. Teps, Praha, 141 p.

KUBÁT, K., TƯMA, E. (1988): Floristické kurzy Severočeské pobočky ČSBS v Doksech a v Rumburku. Severočeskou přírodou, 21, Litoměřice, pp. 15-30.

KUBÁT, K. (1996): Lokalita Liparis loezelii u Jestřebí. Výsledky pozorování v letech 1985 - 1986. Saved in AOPK, středisko Ústí nad Labem.

KUNCOVÁ, J., VONDRÁČEK, J. (1994): Botanická a zoologická pozorování na vybraných mokřadech mezinárodního významu v severočeském regionu (Novozámecký rybník a Břehyňský rybník). Ms., 39 p., 9 tab. Saved in AOPK, středisko Ústí nad Labem.

KUNCOVÁ, J., VONDRÁCEK, J. (1995): Projekt záchrany zvlášt chráněných druhů rostlin $\mathrm{v}$ národní prírodní rezervaci Břehyně-Pecopala a národní přírodní rezervaci Novozámecký rybník. Ms., 2 p. Saved in AOPK, středisko Ústí nad Labem.

LOŽEK, V. (1948): Xerothermní květena Husova kostela v Komárovském pohoří. Věda přírodní, 24, No. 1, Praha, p. 97.

MARŠÁKOVÁ, M. (1973): Popelivka sibiřská. Chráněné druhy rostlin a živočichů. Ochrana přírody, Praha, pp. 15-16.

MATTAUCH, F. (1936): Über die Ligularia sibirica (L.), Cass. Natur und Heimat, 7, Aussig, pp. 57-62.

MATTAUCH, F. (1937): Ein Beitrag zur Kenntniss der Verlandungserscheinungen im Hirschberger Grossteiche. Beih zum. Bot. Centralb., XIV, Dresden.

MATTAUCH, F. (1937): Ueber die Besiedlung der Vegetationsfreien Ostufer und die Enstehung der Polytricheten am Hirschberger Grossteich. Natur und Heimat, Aussig, pp. 34-38.

MICHALIČKOVÁ, Š. ( 1997): Hamerský rybník - ekologický vývoj. Seminární práce, 27 p. Saved in OVM Česká Lípa.

MORAVEC, J. (1967): Arctostaphyllos uva-ursi (L.) Sv. - medvědice léčivá v údolí dolní Otavy a střední Vltavy a její rozšírení v Čechách. Preslia, Praha, 39, pp. 167-177.

NEUHAÜSEL, R. (1959): Poznámky $\mathrm{k}$ některým severočeským nalezištím leknínů. Ochrana pŕ́rody, 4, Praha, pp. 115-116.

NEUHÄUSEL, R., NEUHÄUSLOVÁ (1965): Rostlinná společenstva státní přírodní rezervace Břehyňský rybník u Doks. Preslia, Praha, 37, pp. 170-199.

PETŔÍČEK, V., SY̌KORA, T. (1973): Státní přírodní rezervace Ralsko. Ochrana přírody, 28, Praha, pp. 152-155.

PILOUS, Z. (1974): Mechorosty zájmové oblasti uranových dolů v Hamru. In: Ochranářskopřírodovědecký průzkum oblasti Hamru u České Lípy. TIS Praha, pp.109-154.

PODPERA, J. (1938): Poznámky ku geobotanickému významu květeny na středním Pojizeří. In: Slánský a kol: 250 let gymnasia v Mladé Boleslavi, pp. 99-123.

POHL, F., FIRBAS, F. (1922): Ein Beitrag zur Kenntnis der Flora Nordböhmens. Lotos, Praha, 70, pp. 1-10.

POHOŘELÝ, V. (1962): Dílčí zpráva o výzkumu Pteridophyt SPR Břehyně. Ms., without page numbers. Saved in AOPK, středisko Ústí nad Labem.

PRINZ, K. (1938): Neues von dem Kalksandsteinen des Kummergebirges. Natur und Heimat, 9, Aussig, pp. 36-37. 
PRINZ, K. (19411942): Das Schutzgebiet der sibirischen Goldkolbe (Ligularia sibirica) in Habsteiner Moor bei B. Leipa. Natur und Heimat, 12, Aussig, pp. 10-16.

PROCHÁZKA, F, ČERNOHOUZ, F. (1985): Rozšíření a ekologie Liparis loezelii (L.) L. C. Rich v Československu. Časopis Národního muzea, řada př́r., 154, No. 1, Praha, pp. 10-30.

REUSS, A. (1862): Beiträge zur Flora Böhmens. Lotos, Praha, pp. 235-238.

RYBNÍCEK, K. (1970): Rozšíření Rhynchospora fusca (L.) Ait, fil. v Československu. Zprávy Čs. botanické společnosti, 5, Praha, pp. 155-161.

RYCHTAŘÍK, P. (1985): Zpráva o inventarizačním průzkumu chráněných a ohrožených druhů rostlin v nivě Ploučnice mezi Mimoní a Borečkem v letech 1982 - 1984. In: Základní přírodovědecký průzkum v údolí Ploučnice, úsek Mimoň - Boreček. Základní org. ČSOP 01/33, Praha, pp. 174-226.

RYCHTAŘÍK, P. (1988): Floristické poměry Hamerského jezera a rašeliniště Děvínská louka u Stráže pod Ralskem. In: Záchranná přírodovědná inventarizace Hamr II. Základní org. ČSOP 01/33, Praha, pp. 2-37.

RYCHTARÍK, P. (1990): Carex pediformis C. A. MEY off.macroura (Meinsch). Podp. v Hradčanských stěnách a na Vranovských stěnách u Mimoně. Severočeskou přírodou, 24, Litoměřice, pp. 33-39.

RYCHTAŘÍK, P. (1992): Výskyt Aconitum vulparia Reichenb. u Břevniště - menší lokalita na severovýchodní hranici rozšíření druhu. Severočeskou přírodou, 26 , Litoměřice, pp. 57-59.

RYCHTAŘÍK, P. ( 1996): Rostlinná společenstva Máchova jezera a jejich management. Ms., 16 p., saved in AOPK Praha.

SCHAUTA (1861): Die Carex-Arten in der Umgebung von Niemes. Lotos, 11, Praha, 15 p.

SCHAUTA, J. (1861): Zur Flora der Stadt Niemes und deren Umgebung. Lotos, 11, Praha, pp. 27-31, 48-51.

SCHUSTER, J. (1930): Der sibirische Goldkolbe (Ligularia sibirica) im Habsteiner Moor. Natur und Heimat, 3, Aussig, pp. 102-104.

SCHUSTER, J. (1931): Das Habsteiner Moor als Pflanzenschutzgebiet. Mitt. d. Nordb. Exc. Cl., Česká Lípa, pp. 87-89.

SCHUSTER, J. (1931): Ligularia sibirica na Habštejnském rašeliništi. Krása našeho domova, 23, Praha, pp. 68-69.

SKALICKY, V. (1959): Achyrophorus maculatus (L.) Scop. v Československu. Preslia, Praha, 31, pp. 153-161.

STANČÍK, D. (1995): Časoprostorové změny vegetace Břehyňského rybníku. Diplomová práce, Přírodovědecká fakulta UK Praha, katedra botaniky, 231 p.

STANČIK, D. (1996): Návrh managementu NPR Břehyně-Pecopala - část Břehyně (z hlediska botanického). Ms., 23 p. Appendix. Saved in AOPK Praha.

STUDNIČKA, M. (1986): Záchrana Pinquicula bohemica Kraj. posilováním př́rodní populace. In: Problematika záchrany ohrožených druhů rostlin. Pobočka Čs. VTS při Stř. SUPPOP, Praha, pp.96-103.

STUDNIČKA, M. (1989): Studie kriticky ohroženého druhu Pinquicula bohemica se zřetelem možnosti jeho záchrany. Disertační práce, Botanický ústav AVČR, Praha, Průhonice, $185 \mathrm{p}$.

STUDNIČKA, M. (1994): Jestřebské slatiniště-součást národní př́rodní rezervace Polomené hory. (návrh aktuálních opatření). Liberec. Ms., 12 p. Saved in AOPK, středisko Ústí nad Labem.

SUZA, J. (1948): Doplňky k rozšíření Carex pediformis na Českém masivu. Sborník klubu přírody, 28, Brno, pp. 81-91.

SÝKORA, T. (1970): Lesní společenstva jihozápadní části Hradčanské plošiny. Studie CSAV, 7, Praha, pp. 9-43.

SÝKORA, T. (1973): Relikty smrčin na dně Jestřebské kotliny u Doks a v povodí Ploučnice v severních Čechách. Zprávy Čs.botanické spol., 8, Praha, pp. 196-200.

SÝKORA, T. (1974): Základní př́rodovědecký průzkum Ralské pahorkatiny. In: Ochranářsko-př́rodovědecký průzkum oblasti Hamru u České Lípy. TIS, Praha, pp. 11-64.

SÝKORA, T. (1974): Zpráva o fytocenologickém průzkumu Ralské pahorkatiny. In: Ochranářsko-přírodovědecký průzkum oblasti Hamru u České Lípy. Tis, Praha, pp. 353484. Uloženo v Severočeském muzeu Liberec.

SÝKORA, T. (1974): Provodínská pahorkatina u České Lípy. Živa, Praha, 3, pp. 84-85.

SÝKORA, T. (1975): Floristický rozbor základních krajinných celků Hradčanské plošiny. Preslia, Praha, 47, pp. 75-86.

SÝKORA, T. (1975): Floristický příspěvek k základním krajinným celkům Hradčanské plošiny. Preslia, Praha, 47, pp. 174-184. 
SÝKORA, T. (1977): Současný stav lokality hvězdnice alpské na Ralsku u Mimoně. Živa, Praha, 3, pp. 92-93.

SÝKORA, T. (1977): Syntéza základního př́rodovědeckého průzkumu Ralské pahorkatiny. KSSPPOP, Stipa, 3, Ústí nad Labem, pp. 116-136.

SÝKORA, T. (1979): Příspěvek ke květeně Ralské pahorkatiny - Chrastný vrch (severní Čechy). Preslia, Praha, 51, pp. 141-152.

SÝKORA, T. a kol.(1986): Dílčí zpráva o základním př́rodovědeckém průzkumu Hamerského rybníku a rašeliniště Děvínská louka. Ms., saved in Základní organizace CSOP 01/33 Praha.

SÝKORA, T. (1988): Botanický a geobotanicky významné areály okresu Česká Lípa. Ms., 23 p., saved in OVM Česká Lípa.

SÝKORA, T. (1988): Záchranná přírodovědecká inventarizace Hamr II. Úvod a synthéza provedených výzkumů. In: Záchranná př́ídodovědná inventarizace Hamr II, pp. 1-28. Saved in CSOP, základní organizace 01/33 Praha a AOPK Praha.

SÝKORA, T. (1988): Dílčí zpráva o studiu populace Drosera "renifolia” z CHÚ Swamp (Máchovo jezero). Ms., 2 p. Saved in AOPK, středisko Ústí nad Labem.

TUROŇVÁ, D. (1978): Nově navrhovaná SPR Hamerský rybník u Mimoně. Živa, Praha, 3 , pp. 90-91.

TURONOVÁ, D. (1985): Vegetace Hamerského rybníka u Hamru na Jezeře. (Severní Čechy). Preslia, 57, No. 4, Praha, pp. 335-357.

TURONOVÁ, D.( 1987): Vegetace státní prúrodní rezervace Hradčanské rybníky u Mimoně. Sborník Severočeského Muzea. Př́rodní vědy, 16, Liberec, pp. 127-148.

TURONOVÁ, D. (1988): Kriticky ohrožené druhy rostlin v CSR. Kaprad hřebenitá Dryopteris cristatata (L). A. Gray. Památky a př́roda, 13, No. 1, Praha, 3 p.

TURONOVÁ, D. (1988): Sosiekologická a botanická charakteristika navrhovaného chráněného území Hamerský rybník. In: Základní př́írodovědecká dokumentace Hamr II. Základní organizace ČSOP 01/33 Praha, pp. 339-352.

TUROŇOVÁ, D. (1994): Botanický průzkum mokřadů v severní části Máchova jezera. Ms., 24 p. Saved in AOPK Praha.

VIDNEROVÁ, M. (1967): Fytocenosy a chráněné druhy rostlin na území SPR a chráněných nalezišt v oblasti Ceskolipska a Dokeska. Diplomová práce, saved in státní archiv Litoměřice.

WATZEL, C. (1877): Die Phanerogame Flora des Gebietes von B. Leipa. Communal OberRealschule, Česká Lípa, pp. 1-54.

WURM, F. (1887): Das Kummergebirge die umliegenden Teiche und deren Flora. Festschrift zur Decennalfeier des Nordböhmischen Excursions-Clubs, Lípa, 92 p.

ZIMMERMANN, K., REDER, E. (1926): Aus der Pflanzenwelt Nordböhmens. Mitteilungen des Nordb. Ver. für Heimatforschung und Wanderpflege, Reichenberg, pp.1-9.

ZUMAN, F. (1934): E. Purkyně o květeně okolí Bělského. Bezděz, 5, Česká Lípa, pp. 140-143.

\section{Zoology - invertebrates:}

BOUMA, M. (1983): Zajímavější nálezy motýlů (Lepidoptera) Mimoně a jejího okolí. Zprávy čs. společnosti ent. při CSAV, 19, Praha, pp. 33-39.

BOUMA, M. (1997): Entomologický průzkum Lepidopter bývalého VVP Ralsko. Bezděz, 5, Česká Lípa, pp. 363-377.

FLASAR, I. (1964): Malakofauna Břehyňského a Novozámeckého rybníka na Českolipsku. Sborník Národního muzea v Praze. Acta musei nationalis Prague. Př́rodní vědy, 20, No. 5, pp. 257-284.

FLASAROVÁ, M., FLASAR, I. (1974): Zpráva o výzkumu edafonu (Mollusca, Isopoda) v těžební oblasti Uranových dolù v okolí Hamru u České Lípy. In: Ochranářskopřírodovědecký průzkum oblasti Hamru u České Lípy. TIS, Praha, pp. 485- 542.

GRUND, F. (1941 - 1942): Zwei Seltenheiten des Bösigberges. Natur und Heimat, 12, No. 3 , Aussig, p. 10.

HEYROVSKY, L. (1960): K původu a rozšíření tesaříka alpského (Rosalia alpina L.). Živa, 1, Praha, p. 22.

HONCŮ, M. (1974): Zpráva o entomologickém průzkumu Ralské pahorkatiny. In: Ochranářsko-prrírodovědný průzkum oblasti Hamr u České Lípy. TIS, Praha, s. 1-140.

HONCŮ, M., PULPÁN, J. (1974): Střevlíkovití (Coleoptera, Carabidae) Českolipska. Sborník Severočeského Muzea Ser. Natur, 6, Liberec, pp. 93-149.

HONCŮ, M. (1985): Výsledky průzkumu hmyzu v údolní nivě Ploučnice mezi Mimoní a Borečkem. In: Základní přírodovědecký průzkum údolí Ploučnice, úsek Mimoň Boreček. Základní org. CSOP 01/33, Praha, pp. 306-339. 
HONCŮ, M. (1988): Entomologický průzkum oblasti Hamerského rybníka, k. ú. Hamr u České Lípy. In: Záchranná přírodovědná dokumentace Hamr II. Základní organizace CSOP 01/33, Praha, pp. 268-302.

HONCU், M. (1993): Oodes gracilis A. Villa et B. Villa, 1883, nový druh pro Čechy, (Coleoptera, Carabidae). Fauna Boh. septen., 18, Ústí nad Labem, pp. 155-157.

HONCŮ, M. (1997a): Průzkum vážek (Odonata) na území bývalého VVP Ralsko. Bezděz, 5, Česká Lípa, pp. 269-277.

HONCŮ, M. (1997b): Rovnokřídlí (Orthoptera) bývalého VVP Ralsko. Bezděz, 5, Česká Lípa, pp. 279-294.

HONCUU, M., VONIČKA, P. (1997): Střevlíkovití (Carabidae) bývalého VVP Ralsko. Bezděz, 5, Česká Lípa, pp. 295-357.

HORÁK, L. (1988): Záchranný inventarizační průzkum Hamerský rybník - Děvínská louka. Entomologie - Lepidoptera (motýli). In: Základní př́rodovědná dokumentace Hamr II. Základní organizace ČSOP 01/33, Praha, pp. 179-210.

HRDLIČKA, J. (1963): Základní coleopterologický prưzkum SPR Břehyně-Pecopala. Ms., saved in AOPK, středisko Ústí nad Labem.

HRDLIČKA, J. (1964): Přehled výsledků inventarizačního výzkumu SPR BřehyněPecopala, část Břehyně. Ms., 9 p. Saved in AOPK, středisko Ústí nad Labem.

HRDLIĆKA, J. (1964): K rozšíŕení sametovce alpského (Rosalia alpina L.). Živa, 12, No. 4, Praha, p. 145.

KOPECKY, J. (1962); Entomologický průzkum SPR Břehyně-Pecopala. Ms., 4 p. Saved in AOPK, středisko Ústí nad Labem.

KRAL, H. (1915): Die Käfer aus dem Gebiete des Kummergebirges. Mitt., 42, Ver. Naturfreunde Reichenberg, pp. 49-100.

KRAL, H. (1921): Die Käfer aus dem Gebiete des Kummergebirges - Nachtrag. Mitt., 43, Ver. Naturfreunde Reichenberg, pp. 24-44.

KRAMÁR̆, J., CHALUPSKÝ, J., MINÁR̆, S. (1967): Komáři Severočeského kraje. Sborník Severočeského Muzea. Př́rodní vědy, 3, Liberec, pp. 167-174.

KƯRKA, A. (1997): Arachnofauna vojenského výcvikového prostoru Ralsko (pavouciAranea). Bezděz, 5, Česká Lípa, pp. 237-268

LANGHANS, V., H. (1911): Die Biologie deı luralen Cladoceren Der Grossteich bei Hirschberg in Nordbohmen. Monographien und Abhandlungen zur Internationalen Revue der gesamten Hydrobiologie und Hydrographie, Bd. 3, Leipzig, $101 \mathrm{p}$.

LENDENFELD, R. (1901): Planktonuntersuchungen in Grossteich bei Hirschberg (Böhmen). Vorl. Mitt. in Biol. Centralbl., 21, Dresden, pp. 182-188.

LOŽEK, V. (1949): Nové malakozoologické výzkumy na Českolipsku. Ms., 13 p. Uloženo v AOPK Praha.

MALÝ, V. (1965): O tesaříku alpském. Ochrana přírody, 20, No. 6, Praha, p. 104.

MIKO, L. (1988): Poznámky k hodnocení půdní fauny Hamerského rybníka a rašeliniště Děvínská louka $\mathrm{s}$ rozborem fauny pancírníků (Acarina, Oribatida). In: Základní př́rodovědná dokumentace Hamr II. Základní organizace CSOP 01/33 Praha, pp. 143178.

MOUCHA, J. (1967): K poznání fauny dvoukř́illého hmyzu (Insecta, Diptera) v SPR Břehyňský rybník u Doks. Sborník Severočeského muzea. Přírodní vědy, 3, Liberec, pp. 161-165.

MOUCHA, J. (1968): Temnoskvrnáč borůvkový ve státní př́rodní rezervaci Břehyňský rybník. Ochrana přírody, 23, No. 9, SÚPOP, Praha, př́loha "Ochranářský průzkum", p. 44.

NOVOTNÍ, Z. a J. (1964): Inventarizační seznam Coleopter zjištěných v SPR BřehyněPecopala. Ms., saved in AOPK, středisko Ústí nad Labem.

PEŠKOVÁ, A. (1985): Výskyt tesaříka alpského v SPR Velký a Malý Bezděz a blízkém okolí. Památky a př́roda, 10, No. 6, Praha, p. 335.

SLÁDEČEK, V. (1951): Zooplankton Máchova jezera, Břehyňského a Novozámeckého rybníka. Casopis Národního muzea, odd. př́r., 120, No. 1, Praha, pp. 29-34.

SLÁDEČKOVÁ-VINNIKOVÁ, A. (1958): Př́íspěvek $k$ hydrobiologii Břehyňského a Novozámeckého rybníka. Casopis Národního muzea, odd. přír., 127, No. 2, Praha, pp. 166-182.

SPRENGER, E. (1922): Die Schwimmkäfer des Grossteichgebietes von Hirschberg in Böhmen. Lotos, 70, Praha, p. 239.

STERNECK, J. (1929): Prodromus der Schmetterlingsfauna Böhmens, Karlovy Vary, 297 p. VÁVRA, J., NOVÁK, I., LIŠKA, J., SKYVA, J. (1996): Motýlí fauna př́rodní rezervace "Hradčanské rybníky" u Mimoně(Lepidoptera). Klapalekiana, 32, No. 12, pp. 89-121. 
VÁVRA, J., NOVÁK, I., LIŠKA, J., SKYVA, J. (1997): Motýlí fauna př́rodní rezervace "Hradčanské rybníky" v bývalém vojenském újezdu Ralsko (Lepidoptera). Bezděz, 5, Ceská Lípa, pp. 379-407.

VONIČKA, P. (1997): Příspěvek k poznání koprofágních vrubounovitých (ColeopteraScarabaeidae) bývalého VVP Ralsko. Bezděz, 5, Česká Lípa, pp. 359-362.

ZAVADIL, V., HONCŮ, M. (1997): Listonoh letní - Triops cancriformis cancriformis Linné, 1758 a žábronožka letní - Branchipus schaefferi Fischer, 1834 (Anostraca et Notostraca: Branchiopoda: Crustacea) v bývalém VVP Ralsko. Výsledky předběžného průzkumu. Bezděz, 5, Čská Lípa, pp. 211-235.

ZIMMERMANN, F. (1934): Interessante Kleinschmetterlinge aus dem Habsteiner Moor. Natur und Heimat, Aussig, 5, pp. 34-36.

\section{Zoology - vertebrates:}

BÁRTA, Z. (1985): Vertebratologické poměry inundačního pásma řeky Ploučnice v úseku Mimoň - Boreček. In: Základní přírodovědecký průzkum údolí Ploučnice, úsek Mimoň Boreček. Základní org. ČSOP 01/33, Praha, pp. 366-368.

HOLEČKOVÁ, D. (1985): Ploučnice - vertebratologický průzkum. In: Základní přírodovědecký prủzkum údolí Ploučnice, úsek Mimoň - Boreček. Základní org. ČSOP 01/33, Praha, pp. 340-365.

HONCŮ, M., VONDRÁČEK, J. (1970): Několik poznámek k výskytu čápa černého (Ciconia nigra) v severních Čechách. Ochrana fauny, 4, Bratislava, pp. 112-116.

HONCƯ, M. (1991): Změny početního stavu vodních ptáků na rybnících Českolipska. Panurus, 3, Pardubice, pp. 177-192.

JAPP, G. (1938): Die Tierwelt des Hirschberger Grossteiches. In: Laurin: Hirschberg und sein Teichgebiet. Druck G. Ribert, Haida, pp. 18-30.

JM., MAŠTÁLKO, J. (1948): Poslední medvěd v údolí Ploučnice 1609, Bezděz, 10, Česká Lípa, p. 186.

KOHOUT, L. (1960): Kolonie břehulí v Hamru na Jezeře. Zprávy ČOS, 5, Praha, p. 28.

KUNCOVÁ, J., VONDRÁČEK, J. (1994): Sledování botanických a zoologických poměrủ na vybraných mokřadech mezinárodního významu v severočeském regionu (Novozámecký a Břehyňský rybník). Ms, 39 p., 9 tab. Saved in AOPK, středisko Ústí nad Labem.

KURKA, P., VITÁČEK, Z. (1991): Podpora hnízdění orla mořského na Českolipsku. Atlas ohrožených rostlin a živočichů, 9 , Nika, Praha, 283 p.

KURKA, P. (1991): První prokázané hnízdění jeřába popelavého, Grus grus, v Československu. Sylvia, Praha, pp. 89-94.

KURKA, P. (1997): Dílčí podkladová zpráva $\mathrm{k}$ navrhované národní přírodní rezervaci Dokeské pískovce a mokřady. Ornitologický průzkum území. Bezděz, 5, Česká Lípa, pp. 559-569.

KURKA, P. (1997): Život mořských orlů na severu Čech. Jizerské a Lužické hory, 2, No. 78, Liberec, pp. 8-9.

LÉDL, P. (1985): Výsledky ichtyologického průzkumu na Ploučnici v letech 1982-84. In: Základní přírodovědecký prưzkum údolí Ploučnice úsek Mimoň - Boreček. Základní organizace ČSOP 01/33, Praha, pp. 369-391.

LOOS, K. (1915): Der Wanderfalke in Böhmen. Oester. Monatschrift für Naturwissenschaft. Unterricht, pp. 136-137.

LOOS, K. (1927): Einige Sommerbeobachtungen am Hirsner und Hirschberger Teich im Jahre 1927. Sudetend. Naturschutz, 4 p.

LOOS, K. (1931): Der Biographie unserer Lachmöve. Natur und Heimat, 2, No. 3, Aussig, pp. 65-75.

MASEK, J. (1938): Ze života sokola stěhovavého a jestřába. Bezděz, 9, No. 2, Česká Lípa, pp. 47-49.

MRLÍKOVÁ, Z. (1996): Sysel obecný (Citellus citellus) na lokalitě Mimoň - hřebčín v r. 1996-97. Ms., 20 p. Saved in OVM Ceská Lípa.

NEVRLÝ, M. (1963): Ornitologický průzkum "Strážovské rybníky". Ms., 2 p. Saved in AOPK, středisko Ústí nad Labem.

NEVRLÝ, M. (1974): Zpráva o základním průzkumu zvířeny ptáků Ralské pahorkatiny v letech 1971-73. Ochranár̆sko-přírodovědný průzkum v oblasti Hamru u České Lípy. TIS, Praha, pp. 543-732.

NEVRLÝ, M. (1974): Zpráva o orientačním základním průzkumu drobných savců části Ralské pahorkatiny v letech 1971-73. In: Ochranářsko-přírodovědecký průzkum oblasti Hamru u České Lípy. TIS, Praha, pp.733-770. 
PELC, F. (1988): Ornitologický průzkum lokality rašeliniště Děvínská louka a Hamerský rybník (1986-87). In: Základní přírodovědná dokumentace Hamr II. Základní organizace CSOP 01/33, Praha., pp. 211-267.

ROLLER, J. (1938): Wild und Jagd im Gebiete des Hirschbereger Grossteiches. In: Laurin: Hirschberg und sein Teichgebiet. Druck G. Ribert, Haida, pp. 43-46.

SCHAD-ROADWALK, F. (1912): Die Vogelarten aus der Gegend vom Kummmergebirge bis zur Daubaer Schweiz. Naturw. Zeitschrift Lotos, 60, Praha, pp. 15-24, 38-44.

SCHUSTER, J. (1933): Uhu und Wanderfalke. Natur und Heimat., 4, No. 1, Aussig, p. 1-5.

SCHUSTER, J. (1937): Zum Anfang der Wasserwildjagd. Deutsche Jägerzeitung, 18, pp. 213-215.

SCHUSTER, J. (1938): Die Vogelwelt des Hirschberger Teichgebietes. Natur und Heimat, 9, No. 1, Aussig, pp. 5-10.

SCHUSTER, J. (1938): Die Vogelwelt des Hirschberger Teichgebietes. In: Laurin: Hirschberg und sein Teichgebiet. Druck G. Ribert, Haida, pp. 33-38.

SCHUSTER, J. (1933): Beobachtungen am Uhuhorste. Ornitologischer Jahres-Bericht der Vogelwarte Lotos B. Leipa für das Jahr 1933, pp. 40-50.

ŠRUBAR̆, K. (1997): Přehled pozorovaných ptáků v bývalém vojenském prostoru Ralsko. Bezděz, 5, Ceská Lípa, pp. 571-572.

VITÁČEK, Z. (1992): Výskyt vydry říční na okrese Česká Lípa. Vydra, 3, Havlíčkův Brod, pp. 15-19.

VITÁČEK, Z. (1992): Výskyt vydry říční na okrese Česká Lípa, akce podpora výskytu vydry řiční (Lutra lutra) na Ceskolipsku. Bezděz, 2, Česká Lípa, pp. 87-92.

VITÁČEK, Z. (1994): Plazi okresu Česká Lípa. Bezděz, 2, Česká Lípa, pp. 65-85.

VITÁČEK, Z. (1997a): Výsledky faunistického výzkumu obratlovcủ prováděného v bývalém VVP Ralsko. Kruhoústí (Cyclostomata), Ryby (Pisces, Osteichthyes). Bezděz, 5, Ceská Lípa, pp. 409-427.

VITÁCEK, Z. (1997b): Výsledky faunistického výzkumu obratlovců prováděného v bývalém VVP Ralsko. Obojživelníci (Amphibia). Bezděz, 5, Česká Lípa, pp. 429-452.

VITÁČ́EK, Z. (1997c): Výsledky faunistického výzkumu obratlovců prováděného v bývalém VVP Ralsko. Plazi (Reptilia). Bezděz, 5, Česká Lípa, pp. 453- 471.

VITÁČEK, Z. (1997d): Výsledky faunistického výzkumu obratlovcủ prováděného v bývalém VVP Ralsko. Ptáci (Aves). Bezděz, 5, Česká Lípa, pp. 473-491.

VITÁCEK, Z. (1997e): Výsledky faunistického průzkumu obratlovců prováděného v bývalém VVP Ralsko. Savci (Mammalia). Bezděz, 5, Česká Lípa, pp. 493-524.

VONDRÁČEK, J. (1970): Ornitologické pozmámky ke státní přírodní rezervaci BřehyněPecopala. Vlast. sešity, řada ochrany přírody, 1, Ústí nad Labem, pp. 73-81.

VONDRÁČEK, J. (1976): Sokolovití dravci v Severočeském kraji. Sborník Severočeského muzea. Ser. Natur, 8, Liberec, pp. 64-78.

VONDRÁČEK, J., HONCŮ, M. (1990): Jeřáb popelavý, Grus grus (L.) v severočeském kraji. Fauna Boh. Septen., 14-15, Ustí nad Labem, pp. 85-88.

VONDRÁČEK, J. (1989): IPZ obratlovci státní př́rodní rezervace Břehyně-Pecopala. Ms., Part I - 32 p., Part II - 9 p. Saved in AOPK, středisko Ústí nad Labem.

VONDRÁČEK, J. (1995): Avifauna NPR Břehyňský rybník. Fauna Boh. Septen., 20, Ústí nad Labem, pp. 43-65.

VOŽENÍLEK, P. (1966); Inventarizační průzkum SPR Břehyně-Pecopala. Ms., 4 p., saved in AOPK, středisko Ústí nad Labem.

ZAVADIL, V. (1995): Hnízdění vodouše kropenatého (Tringa ochropus) v bývalém VÚ Ralsko (severní Čechy). Zprávy čs. spol. ornitologické, 41, Praha, pp. 9-10.

\section{Su m m ary}

\section{BIOLOGICAL AND LANDSCAPE VALUES OF THE FORMER RALSKO MILITARY TRAINING AREA}

The nature of the former military training area Ralsko, in spite of the damage caused by the use of the area for military purposes and for uranium mining, is surprisingly well preserved and, at least in some parts, it belongs to the richest parts of Bohemia. About 1,200 species of higher plants and almost 90 plant associations have been registered. There is also an imposing number of endangered higher plants: 145 species, two of which are endemic species: Dactylorhiza bohemica and Pinquicula bohemica. Several species which only sporadically occur in the Czech Republic are important such as, e.g. Hammarbya 
paludosa, Minuartia setacea, Carex pediformis subsp. macroura, Astragalus arenarius, and Chimaphila umbelllata. Similar results were also obtained by a zoological study in the course of which several thousands of invertebrate species, including two entirely new ones and several species new to the Czech Republic, were found. A survey of the vertebrate fauna proved occurrence of one species of cyclostomes, 26 fishes, 12 amphibians, 6 reptiles, 264 birds and 44 mammals. In the mentioned region, there is the only spontaneous nesting place of the Haliaeetus albicilla and the first new nesting place of Grus grus registered in the Czech Republic. Among the animals living here, 18 species, including e.g. Rosalia alpina, Ergates faber, Branchipus schaefferi, Triops cancriformis, Rana ridibunda, Vipera berus and Lutra lutra, belong to the category of critically endangered species.

The most valuable areas are included in the system of nature reserves according to the law No. 114/1992 and notice 395/1992 about the protection of nature and the landscape. In the demarcated region eleven areas are proclaimed small-scale nature reserves. One of these, the Břehyně-Pecopala Nature Reserve, is protected in the category of national nature reserves, the other three belong to the category of nature reserves: the Hradčany Ponds, the Malý and Velký Bezděz and Ralsko Hills. Seven areas range in the category of nature monuments, see Vranovské skály Rocks at the southern slopes of the Ralsko Hill, and the hills of Siroký kámen, Stohánek, Malý and Velký Jelení vrch, Děvín - Ostrý and Schachtenstein, the Divadlo Rocks and the Černý rybník Pond peat-bog in the vicinity of Hamr. Temporary protection has been proclaimed in the area of the Ploučnice River wetlands, the Hradčany Hills and the Ploučnice alluvial plain. The importance of several of these protected areas exceeds the borders of the Czech Republic. Further areas are proposed for protection. The most valuable parts of the area will be included in the National Nature Reserve "Dokeské pískovce a mokřady" (Doksy Sandstones and Wetlands) which will have a disjunctive character. In this region 16 areas have been selected to constitute the core of the reserve, surrounded by a protective zone. The main motive for protection of this area is its unique concentration of very rare plant and animal species and also of associations, especially the relict ones. In this Nature Reserve there are wood complexes of different kinds, water and wetland ecosystems, meadows, important geological and geomorphologic features. A very important motivation for the proclamation of this nature reserve is the extinction or annihilation of several rare species which formerly lived in this area, and the present desolate state of populations of several species.

(The author is with the District Museum, náměsti Osvobození 297, 47001 Česká Lípa.)

Arrived at the editors office on May 25, 1998

Recommended for publication by Václav Poštolka and Zbyněk Ryšlavý 